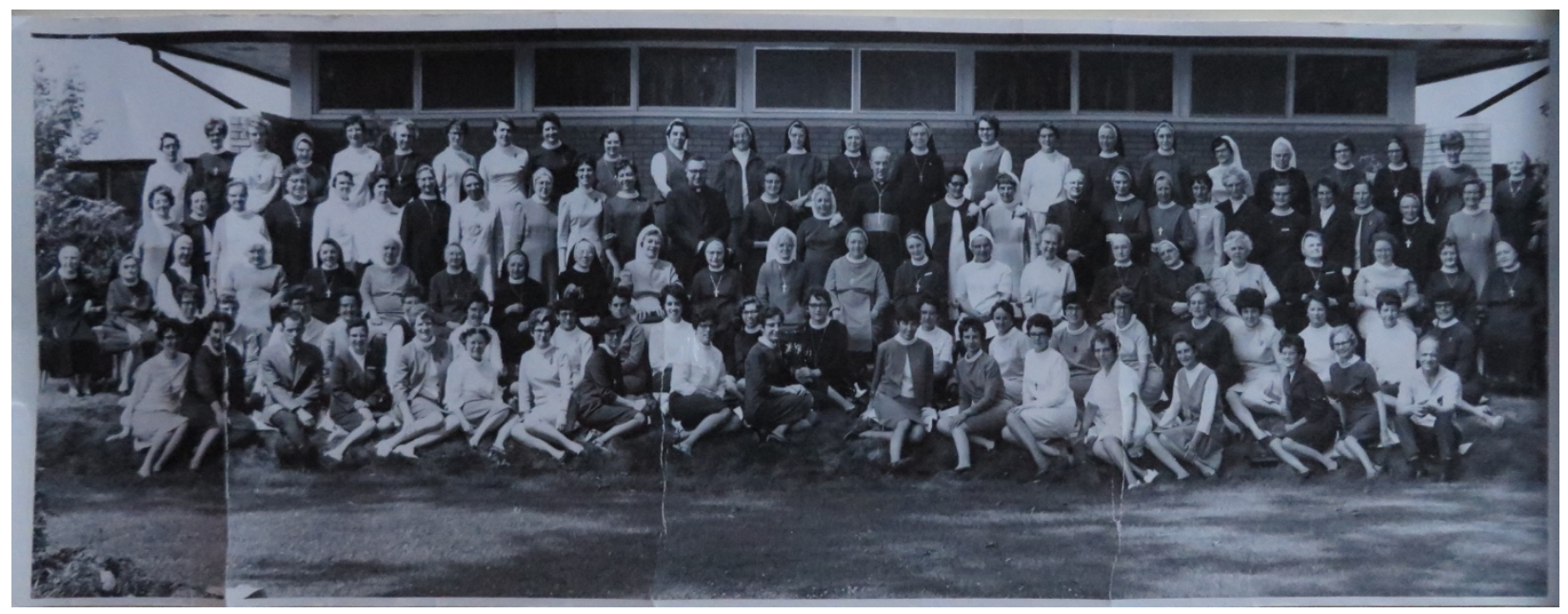

Provincial Assembly, 1970

ISSN 2560-8371

(C) Encounters in Theory and History of Education 27 


\title{
An analysis of the fundamental shift in Catholic secondary religious education during the long sixties, 1955-1973
}

\author{
Análisis del cambio fundamental en la educación religiosa de la secundaria \\ católica durante los largos años sesenta, 1955-1973
}

\section{Analyse du changement fondamental dans l'éducation religieuse au secondaire catholique au cours des années 1955-1973 en Amérique du Nord}

\author{
Joe Stafford \\ Queen's University
}

\begin{abstract}
This paper examines the fundamental shift in Catholic secondary religious education in North America during the long sixties, 1955-1973. Special focus is given to the Canadian province of Ontario. This paper argues that this fundamental shift involved a major change in orientation as strict Neo-Thomism was abandoned after Vatican II along with the traditional teacher-led pedagogy of rote-memorization. It was replaced with a more subjective approach, emphasizing the developmental nature of Church tradition and the inner transformation of the individual. Teaching methods also changed with more student-centred strategies adopted. This paper also examines the causes and consequences of this fundamental shift, concentrating on the impact of the cultural changes of the long sixties and Vatican II. This paper argues that this shift was a needed one, but that it was too extreme leading to a period of considerable confusion in Catholic secondary religious education. ${ }^{1}$
\end{abstract}

Keywords: Long sixties, Ontario, student-centred teaching, Vatican II, Catholic secondary education

\section{RESUMEN}

Este artículo examina el cambio fundamental en la educación religiosa de la secundaria católica en América del Norte durante los largos años sesenta, 1955-1973. Prestando especial atención a la provincia canadiense de Ontario, el artículo argumenta que este cambio tuvo grandes efectos, pues a medida que el estricto neotomismo fue abandonado tras el Vaticano II, se fue abandonando la pedagogía tradicional magistro-céntrica dirigida a la memorización. El neotomismo fue reemplazado por un enfoque más subjetivo, que enfatizaba el carácter evolutivo de la tradición de la Iglesia y la transformación interior del individuo y, al mismo tiempo, los métodos de enseñanza adoptaron más estrategias centradas en los estudiantes. El artículo examina las causas y consecuencias de este cambio fundamental, en particular los cambios culturales de los años sesenta y el Vaticano II. Argumenta, asimismo, que la transformación era necesaria, pero demasiado

\footnotetext{
${ }^{1}$ I would like to thank my PhD supervisor, Dr. Rosa Bruno-Jofré, for her constant support and guidance in the completion of this paper.
}

ISSN 2560-8371 
radical, lo que condujo a un período de considerable confusión en la educación religiosa de la secundaria católica.

Palabras clave: Los largos años sesenta, Ontario, enseñanza centrada en los alumnos, educación católica secundaria

\section{RÉSUMÉ}

Cet article examíne le changement fondamental dans l'éducation religieuse au secondaire catholique en Amérique du Nord au cours des années 1955-1973. L'auteur prête une attention spéciale à la province canadienne de l'Ontario. Il soutient que ce glissement fondamental implique un changement d'orientation majeur alors que le néothomisme strict est abandonné après Vatican II, ainsi que la pédagogie traditionnelle d'«apprendre par cœur» qui est dirigée par l'enseignant. Cette pédagogie est remplacée par une approche plus subjective mettant l'accent sur le caractère évolutif de la tradition de l'Église et la transformation intérieure de la personne. Les méthodes d'enseignement changent aussi en faveur de stratégies plus centrées sur l'étudiant. L'article examine aussi les causes et les conséquences de ce changement fondamental, en particulier les changements culturels des années soixante et de Vatican II. L'auteur soutient que le changement était nécessaire mais qu'il a été trop extrême ce qui a conduit à une période de confusion dans l'éducation religieuse au secondaire catholique.

Mots-clés: les années soixante, l'Ontario, l'enseignement centré sur l'étudiant, Vatican II, l'éducation secondaire catholique.

Who are we? It was a question that haunted many Catholics after Vatican $\mathrm{II}^{2}$ A distinct Catholic culture - which had sustained Catholics for decades if not for centuries - had collapsed. Traditionally obedient and deferential to clerical authority, most Catholics had accepted their faith as it was taught to them without seriously questioning its essential tenets and rituals. It was not always even necessary to understand them, as one young student explained in 1968: "I don't know why we believe it, or why we do this or that. It's the law and we have to."3 Many Catholics were bewildered and confused at the sudden rapid change in their church. Along with the collapse of the dominant Catholic culture, a fundamental shift occurred in Catholic secondary religious education in North America during the 'long sixties', 1955 to 1973. This shift involved a major change in orientation from the objective, Neo-Thomistic understanding of the immutability of Church doctrine with its emphasis on the intellect as the means to achieve religious knowledge to a subjective understanding of the historical developmental nature of Church doctrine with an emphasis on the importance of the individual's inner conversion. Accompanying this change in orientation were significant changes in pedagogy as Catholic educators focused less on knowledge accumulation and adopted a child-centered approach. Central to this fundamental shift was the impact of Vatican II, in particular how Catholic educators understood the resulting 16 documents, especially the major document on education, The Declaration on Christian Education. One of the major problems with the Declaration on Christian Education was the lack of clarity. Even though at Vatican II the bishops intended for the Church to be more 'open' to the modern world and to enhance the role of the laity within the Church, the Declaration did not clearly address how

\footnotetext{
${ }^{2}$ Philip Gleason, "In Search of Unity: American Catholic Thought 1920-1960," The Catholic Historical Review Vol 65 No. 2 (1979): 186-87, http://www.jstor.org/stable/25020551

${ }^{3}$ Sub Commission on Youth. The Diocese of London Synod II. The London Diocese Archives, DUA, Bishop E.G. Carter, Box 25, File 28.
} 
Catholic educators were to achieve this 'openness' nor did it explain the new role of the laity in Catholic education. Little guidance was provided. The Declaration did, however, attempt to maintain a balance between the needed reforms and traditional Catholic education - a balance that was not achieved in the years after Vatican II.

Another major factor in shaping this fundamental shift was the changing nature of the North American society in which Catholics lived. Prior to the long sixties, Christianity enjoyed a cultural hegemony in a predominantly Protestant North America. Within this society Catholics maintained their own distinct culture, sharing a set of values and a world perception that some scholars have called the "Catholic mind"-reflecting what Bernard Lonergan termed as a classicist culture in which the larger community determined meaning and value, not the individual themselves. ${ }^{4}$ Before Vatican II Catholic leadership attempted to isolate Catholics from the dominant Protestant culture, resulting in what some Catholics scholars called 'ghetto' Catholicism. It is within this context that the Magisterium imposed a strict interpretation of Neo-Thomism on Catholic schools despite increasing criticism of this interpretation among educators and scholars.

After World War II, however, the dominant North American culture began to change. An unprecedented period of prosperity led to a dramatic increase in population, the 'baby boom' generation, to a dramatic growth in suburbs, and to a culturally pluralistic society because of immigration. A now affluent and consumer oriented society also became increasingly secular with the 1960s being the "hinge decade" between the more religious 1940s and 1950s and the more secular 1970s and 1980s. ${ }^{5}$ At the same time society became more focused on the rights of the individual, a natural development given the child-centred nature of society as a result of the increased number of children. Most parents, deprived of the opportunity to enjoy the benefits of prosperity, because of the Great Depression and World War II, and longing for social and economic stability, were determined that their children would enjoy these benefits. The education that these children received also reflected the new priorities that emerged after years of fighting totalitarian regimes: democracy, human rights, and social justice. Authoritarianism in all its forms was considered a danger. In the long sixties, many young people, conditioned to question authority, lost faith in the so-called traditional authority, particularly after the assassination of John F. Kennedy and the United States' deepening involvement in the Vietnam War. It is not an overstatement to say that a 'crisis of authority' marked the era. Young people questioned the "received wisdom" of the adult world, of the "Establishment," 6 resulting in a proliferation of protest movements, youth radicalism, and the sexual revolution as the dominant social conservative mores and the institution of marriage itself were challenged. What emerged during the long sixties was an affluent, secular and pluralistic society in which individuals, and not any traditional authority, determined their own meaning and moral values. The Christian cultural hegemony had collapsed. Ironically, because Protestants and Catholics shared the same essential Christian beliefs and morals, this Christian hegemony had actually provided a layer of protection for the distinct Catholic culture despite the anti-Catholicism common among many Protestants. Once this hegemony collapsed, both Protestants and Catholics shared the same secular,

\footnotetext{
${ }^{4}$ Richard Rymarz, "Conversion and the New Evangelization: A Perspective from Lonergan" The Heythrop Journal 51, no. 5 (2010):754, doi: 10.1111/j1468-2265.2009.00545x.

${ }^{5}$ Hugh McLeod, "Reflections and New Perspectives," in Nancy Christie and Michael Gauvreau, editors, The Sixties and Beyond: Dechristianization in North America and Western Europe, 1945-2000 (Toronto: University of Toronto Press, 2013), 453.

${ }^{6}$ Doug Owram, Born at the Right Time: A History of the Baby Boom Generation (Toronto: University of Toronto, 1997), 126-27.
} 
individualistic culture. Ultimately, then, one of the critical factors in the fundamental shift in Catholic education was the inability of the Church to isolate Catholics from this new dominant culture as Catholics participated in the postwar prosperity and were assimilated into the mainstream culture, resulting in the shattering of the Catholic mind.

Education in Ontario was not immune to the cultural changes of the long sixties, resulting in major educational reforms that also affected Catholic schools. ${ }^{7}$ Prominent among these changes were a significant degree of decentralization or 'democratization' with local school boards assuming more authority than they had previously possessed, and the adoption of assessment and evaluation procedures along with teaching strategies that mirrored the new emphasis on childcentred education. It was here that the reforms of Vatican II and the Ontario educational reforms intersected: Vatican II also highlighted the rights of the individual and individual conscience as the Church attempted to be open to the modern world. ${ }^{8}$ The Church underwent a significant change in power structure as well with the adoption of the principle of subsidiarity which held that when there was a legitimate authority dealing with an issue, a superior authority did not interfere-a change in power structure that would impact secondary Catholic education.

A configuration of different factors, cultural, educational, and religious, shaped the fundamental shift in Catholic secondary religious education, a needed change since the Magisterium policy of imposed Neo-Thomism was no longer appropriate in terms of either theology or Church governance. However, the shift was somewhat extreme with much of traditional Catholic education abandoned. The traditional rote-memorization pedagogy was no longer acceptable, replaced by a child-centred approach that adopted progressive teaching strategies, yet this led to an overall lack of understanding of Church practice and doctrine. NeoThomism was rejected, but the emphasis on subjectivity and individual conscience led many educators to question traditional truths of Catholicism. As well, religion was no longer considered a serious academic subject. A lack of leadership was also evident given the principle of subsidiarity and the decentralization of Ministry authority, which although admirable concepts, led to a lack of consistency in terms of education. Overall, then, the long sixties were a period of considerable confusion for Catholic educators. By the mid-1970s, however, a concerted effort was made to restore a sense of balance in Catholic secondary education with a renewed focus on teaching Church doctrine without abandoning the impressive educational reforms achieved during the long sixties.

\section{The Catholic Mind, Strict Neo-Thomism, and Divini Illus Magistri}

\footnotetext{
${ }^{7}$ The history of Catholic schools is a complicated one. Catholics had been granted their own separate school system early in the $19^{\text {th }}$ century, but it fell under the direct supervision of the provincial Department of Education. Catholic schools were not entirely 'separate.' Catholic schools were to be tolerated at best and Catholics were forced to fight for their educational rights. This struggle has been well-documented. By the 1960s the Catholic secondary school system was a hybrid one: grades 9 and 10 received government funding, albeit at a lower rate than its public counterpart, but the senior grades operated as private schools. An excellent summary is provided by Terri-Lynn Kay Brennan's "Roman Catholic Schooling in Ontario: Past Struggles, Present Challenges, Future Direction?" Canadian Journal of Education 34, 4 (2011): http://www.jstor.org/stable/canajeducrevucan.34.4.20

${ }^{8}$ A significant change in the power structure occurred as well. The 'democratic' principle of subsidiarity was adopted, meaning that when there was a legitimate authority dealing with an issue, a superior authority did not interfere.
} 
In order to understand the nature of the fundamental shift in Catholic secondary education, it is critical to understand the Catholic culture that existed before Vatican II. One of the leading theologians of the $20^{\text {th }}$ century, Bernard Lonergan, referred to the dominant pre-Vatican II Catholic culture in North America as "classicist." Catholic belief permeated the entire culture, which did not understand itself as one culture among many, but as "the only culture any right-minded and cultivated person would name as culture."9 Essential to this culture was the deeply embedded respect for antiquity, in particular the Greco-Roman classical era - an antiquity that had been assimilated into Christian culture. ${ }^{10}$ In terms of education, the different academic disciplines were integrated, infused with Catholic theology and philosophy, while remaining distinct disciplines. ${ }^{11}$ Catholic thought therefore permeated the entire educational system and shaped the individual's own self-identity and perception of reality. The term the "Catholic mind" encapsulates the essential meaning of classicism: Catholics shared the same values and world view both of which remained virtually unchanged. $^{12}$

During the period 1920-1960 this classicist culture became identified largely with NeoThomism in North America, in particular strict Neo-Thomism. ${ }^{13}$ For example, this Neo-Thomistic classicism permeated Pope Pius XI's encyclical, Divini Illus Magistri, On Christian Education of Youth, issued in 1929 in honour of the $50^{\text {th }}$ anniversary of Aeterni Patris - the most important papal statement on education until Vatican II. This encyclical "set the agenda" for Catholic education for the next thirty years. ${ }^{14}$ The "cultivation of the Catholic mind" was the "ideal of Christian Education" proposed by the encyclical. ${ }^{15}$ The encyclical emphasized that Christ "conferred infallibility" on the Pope, "commanding" the church to teach His doctrine, and, reflecting Neo-Thomistic philosophy, declared that Christ had entrusted the church to "keep whole and inviolate the deposit confided to her...in accordance with revealed doctrine." "This "deposit" was immutable. The encyclical also reflected the dominant "theological anthropology" articulated

\footnotetext{
${ }^{9}$ Rymarz, "Conversion and the New Evangelization: A Perspective from Lonergan," 754.

${ }^{10}$ Bernard Lonergan, "The Future of Christianity" in A Second Collection: Papers by Bernard J.F. Lonergan, S.J. ed. William F.J. Ryan et al. (London: Darton, Longman \&Todd, 1974), 160.

${ }^{11}$ G. A. McCool, "Spirituality and Philosophy: The Ideal of the Catholic Mind", The Sacred Heart Review, Vol. 10: Issue 1 (1989): 29-30, http://digitalcommons.sacredheart.edu/shureview.

${ }^{12}$ R.G. Collingwood uses the term "substantialism" to define classicism and the accompanying mindset which held that major social entities like the church sailed "like a hermetically sealed and fully defined substance through the sea of history without being affected by it." J.W. O'Malley, What Happened at Vatican II (Cambridge: Belknap Press of Harvard University Press, 2010), 37.

${ }^{13}$ Gerald A. McCool, "The Tradition of Saint Thomas in North America: At 50 Years" The Modern Schoolman. Volume 65, Number 3 (1988): 188-89, DOI: 10.5840/schoolman198865328. Neo-Thomists contended that there had been no substantial change in church doctrine since the days of the apostles because they believed that this marked the end of God's revelation. Church doctrine was therefore immutable and beyond the influence of historical change. It was further contended that St. Thomas Aquinas had inherited the "deposit of faith" and provided a brilliant synthesis. With Pope Leo XIII's encyclical, Aeterni Patris, On the Restoration of Christian Philosophy, Neo-Thomism was adopted as the official philosophy of the Church and therefore taught in Catholic schools. By the early $20^{\text {th }}$ century the Magisterium insisted upon a strict interpretation of Neo-Thomism as it faced increasing opposition from Catholic scholars who questioned the essential precepts of Neo-Thomism, particularly its rigid intellectualism that denied the importance of the subjective, inner spiritual experience of the individual.

${ }^{14}$ Brian Kelty, "Toward a Theology of Catholic Education," Religious Education Volume 94, no. 1 (1999): 11. DOI: 10.1080/0034408990940102, p. 11

${ }^{15}$ Gerald McCool, "Spirituality and Philosophy: The Ideal of the Catholic Mind" Sacred Heart University Review: Vol. 10: Issue 1, Article 3 (1989): 30. http://digitalcommons.sacredheart.edu/Shureview.

${ }^{16}$ Pope Pius XI, Divini Illius Magistri, section 16
} 
in the 1854 definition of the Immaculate Conception that emphasized the sinful nature of humanity - an anthropology accepted by strict Neo-Thomists. Original sin has affected human nature with two major failings: "weakness of will and disorderly inclinations" both of which cannot be corrected without the "supernatural truth" and the "grace" provided by the church. Without the church "it is impossible to control the evil impulses." 17 All forms of education must therefore consider the impact of original sin and consequently the church was opposed to any form of progressive education that recognized the "self-government and unrestrained freedom" of the child and which accordingly, diminished the role of the teacher in the educational process. ${ }^{18}$ The teacher assumed an essential role in Catholic education as the moral and intellectual guide to the youth, upholding the ultimate purpose of education: spiritual perfection and salvation. Indeed, the Church wanted to isolate the youth from what it considered the modern "moral poison which at that inexperienced and changeable age more easily penetrates the mind and more rapidly spreads its baneful effects." 19 Thus, the Church emphasized the traditional role of the family in the education of Catholic children, "forbidding" parents to send their children to non-Catholic schools unless they had no other option, and even then, only with the permission of church authorities. ${ }^{20}$ Such efforts to isolate students from the modern world led many critics to refer to classicism as Ghetto Catholicism. ${ }^{21}$ The encyclical thus embraced the strict Neo-Thomist interpretation of the role of the Church in education, a vital role given the perceived innate weaknesses of human nature, and as the defender and interpreter of the 'deposit' of doctrine and religious truth.

\section{Strict Neo-Thomism and Catholic Education}

This encyclical did indeed set the 'agenda' for Catholic education in North America. The Church was vigilant in assuring that Catholic schools adhered to this strict Neo-Thomism, and thus in theology classes, students were unlikely to study the works of outstanding European Catholic scholars who were questioning Neo-Thomism. ${ }^{22}$ Throughout this period the "Thomistic establishment reigned" in the vast majority of American colleges and universities where an "explicitly Catholic point of view" was evident in the teaching of most secular subjects, ${ }^{23}$ and by the late 1920s, Neo-Thomism had succeeded in reaching "the level of a popular ideology among American Catholic educators." 24

This was certainly the case in the Archdiocese of Toronto which made a concerted effort to impose strict Neo-Thomism on Catholic high schools following the instructions from the Magisterium. The Archdiocese was obedient in adhering to the ordinances from the Sacred Congregation of the Council 1935 Decree on the Better Care and Promotion of Catechetical Education, which cited several canon laws to justify its call for improvement in religious instruction, emphasizing the critical importance of effective teacher-training and of treating

\footnotetext{
${ }^{17}$ Pope Pius XI, Divini Illius Magistri, sections 58 and 59

${ }^{18}$ Divini, section 60

${ }^{19}$ Divini, section 24

${ }^{20}$ Divini, section 35 and 79

${ }^{21}$ R. Scott Appleby and John H. Hass, "The Last Supernaturalists: Fenton, Connell, and the Threat of Catholic Indifferentism," U.S. Catholic Historian, Volume 13. No. 2 (1995): 49, http://www.jstor.org/stable/25154064.

${ }^{22}$ Hitchcock, J. and D.J. O’Brien. 1985. "How Has American Catholic Intellectual Life Change Over the Past Thirty Years?" U.S. Catholic Historian. Vol. 4, No. 2 (1985): 178. http://www.jstor.org/stable/25153726. p.178

${ }^{23}$ Hitchcock, J. and D.J. O’Brien. "How Has American Catholic Intellectual Life", 177.

${ }^{24}$ Hitchcock, J. and D.J. O’Brien. "How Has American Catholic Intellectual Life”, 194.
} 
religious instruction as the most significant subject offered in Catholic schools. ${ }^{25}$ In demanding that a Diocesan Catechetical Office, which would "control the entire catechetical instruction in the diocese," $"$ "6 the Council sought to ensure that in all parishes, schools and colleges "Christian doctrine be taught by properly prepared teachers according to the traditional form of the Church." 27 A detailed questionnaire was distributed to the bishops who were to complete it every five years in order to inform the Magisterium of the "state of the diocese entrusted to them. ${ }^{28}$ The Archdiocese of Toronto obediently completed this questionnaire in 1941, informing the Council that a Catechetical Office existed known as the Office of Religious Instruction, and that in accordance with the Council's instructions, a Catechetical Day was celebrated every year in order to emphasize the importance of Church doctrine. ${ }^{29}$ In order to enhance the status of religion as an academic subject as instructed by the Council, the Archdiocese mandated that high schools have final religion exams ${ }^{30}$ with the grade 12 exam given special status: the graduation exercises for all those who passed the Diocesan religion exam were held at St. Michael's Cathedral on Catechetical Day. ${ }^{31}$

An analysis of the mandated textbooks also indicates that the Archdiocese followed the ordinances from Rome, particularly in teaching strict Neo-Thomism. For example, the mandated textbook in the 1940's, Religion: Doctrine and Practise, emphasized one of the major tenets of strict Neo-Thomism, that there had been no change in the "deposit of faith," that is the "sum of revealed doctrines," since the death of the last apostle - a deposit that St. Thomas Aquinas inherited. Furthermore, "no new revelation has been proposed by the Church" and "whenever there is a question of settling or defining a disputed point of faith, the Church always decides according to the teaching of tradition." 32 This text also emphasized traditional subjects such as indulgences, and typical of Catholic education at this time, denied that the Church had committed any errors, stating that Martin Luther had a "wrong notion concerning indulgences." "Enemies of the Church have also accused her of selling indulgences. This is a gross calumny." 33 In the 1950s, the

\footnotetext{
${ }^{25}$ The Sacred Congregation of the Council Decree on the Better Care and Promotion of Catechetical Education, National Center of the Confraternity of Christian Doctrine, Washington D.C. (Archdiocese of Toronto Archives, MGSO25.65 a. p. 12. The extent to which the Council was concerned with the quality of education is clearly indicated by the strong language in the decree: "...faith in our day is sickly and almost to be accounted dead, for no other cause than the careless, negligent teaching of Christian doctrine, or the omission of this duty altogether." (p. 45)

${ }^{26}$ The Sacred Congregation, Archdiocese of Toronto Archives, 10.

${ }^{27}$ The Sacred Congregation, 10.

${ }^{28}$ The Sacred Congregation, 13.

${ }^{29}$ Questionnaire on the Teaching of Christian Doctrine, the Archdiocese of Toronto Office of Religious Instruction, Archives of the Roman Catholic Archdiocese of Toronto, GSO25.65 (b) (hereafter ARCAT)

${ }^{30}$ Questionnaire on the Teaching of Christian Doctrine, 12. It was not only the Archdiocese of Toronto that adopted final religion exams. The Archdiocese of Kingston for example had such exams. The 1957 final senior exam consisted mainly "memory-recall questions that required little analysis such as "What is the sacrament of Holy Orders? Under what circumstances did Our Lord institute this sacrament?" The Archives of the Sisters of Providence, Kingston, 13B2, 309.5.

${ }^{31}$ Report on "Diocesan Catechetical Activities" for 1944-45. ARCAT, EDSC04.66

${ }^{32}$ Francis B. Cassilly, S.J, Religion: Doctrine and Practice. (Chicago: Loyola University Press, 1934), $350-51$.

${ }^{33}$ Cassilly, Religion, 277. Emmett Carter in his 1954 paper, "Child Study in Relation to the Curriculum: The Adolescent Period" denounced such denials. According to Carter, "for the last century or more there has certainly been a tendency among Catholic writers to make history a department of apologetics and to idealize mediaeval culture in order to exalt their religious ideals." He argues that high school students need to be taught the truth, asking a very practical question: "How much better that they should hear these truths from kind lips and Catholic sources than that they should be obliged to accept them later, to their chagrin, from hostile sources." (p. 20).
} 
mandated series of textbooks, The Quest for Happiness, which was used throughout English Canada, ${ }^{34}$ also adopted strict Neo-Thomism. The first unit of the grade 9 textbook, Our Goal and Our Guides, for example, explained that while human reason guided an individual towards religious truth, it cannot be "trusted too far," and that faith was the "better guide." Students were also warned that the root cause of serious error was the "errors of reasoning" caused by "original sin, which darkened our understanding and weakened our will." "35 Students were also assured of the "guaranteed certainty" of the Gospels, rejecting outright modern biblical criticism even though the Church itself permitted it. ${ }^{36}$ Furthermore, teacher professional development courses and conferences both emphasized strict Neo-Thomism in order to prepare teachers to teach religion according to Magisterium ordinances, and to ensure that the students passed their final exams. ${ }^{37}$ Accordingly, teachers needed to "endeavour to develop a Catholic mind" in order to fulfil their vocation. $^{38}$

\section{The Shattering of the Catholic Mind}

This Catholic mind was not restricted to the classroom as a general consensus exists among scholars that Bernard Lonergan was correct in asserting that Neo-Thomistic classicism permeated North American Catholicism prior to Vatican II with Catholics convinced that they possessed religious truth. ${ }^{39}$ Ordinary Catholics seemed to share the self-assured confidence of the leading proponents of strict Neo-Thomism that there was only one truth about God, espoused in the philosophy of St. Thomas whose theology was "not just one theology among others; it was an exposition of the mind of God." 40 In the 1940s and the 1950s Catholics appeared content to belong to the "one true Church." ${ }^{41}$ Lonergan testified to the supreme confidence of the Neo-Thomists, observing that classicist culture "made no provision for the possibility of its own demise." 42 The Church had also established "Catholic Action," an umbrella organization that oversaw a multitude of Catholic social and charitable groups that operated within the Catholic world-wide community, insisting that their members adhere to Neo-Thomist teachings. Present in parishes across North America, Catholic Action emphasized the integralist nature of Catholic thought. According to a leading American scholar, James Courtney Murray, once individuals possessed the "splendid organic wholeness" of the Catholic faith they also possessed a "tightly integrated system of motives" to inspire them to moral action under the direction of the Church. ${ }^{43}$ Novelists and

\footnotetext{
${ }^{34}$ ARCAT, MGDS59.07A and MGDS5907B

${ }^{35}$ Clarence Elwell, Clarence, Our Quest for Happiness, Book One, Our Goal and Our Guides. (Chicago: Mentzer, Bush, and Company, 1951), 38.

${ }^{36}$ In Pius XII's 1943 encyclical, Divino Afflante Spiritu, On Promoting Biblical Studies, Catholics were permitted to use this method. was permitted.

37 "Teaching of Religion," prepared by the inspector for Catholic schools, J.M. Bennett, for the Catechetical Conference for Kingston. The Archives of the Sisters of Providence, Kingston. 13B2, 304.5, 1

38 "Teaching of Religion," 4

${ }^{39}$ The actual extent to which North American Catholics shared this Catholic mind and Neo-Thomism classicism is to difficult to determine given the size of North America and the ethnic diversity within the Catholic community. A consensus exists, but more research is still need to determine the degree to which this classicism affected the lives of ordinary Catholics.

${ }^{40}$ Philip Gleason, "In Search of Unity: American Catholic Thought 1920-1960," The Catholic Historical Review 65, no. 2 (1979): 203. http://www.jstor.org/stable/25020551.

${ }^{41}$ Patrick McNamara, Conscience First, Tradition Second: A Study of Young American Catholics (New York: State University of New York Press, 1991), 17.

${ }^{42}$ Lonergan, "The Future of Christianity," 160.

${ }^{43}$ Gleason, Keeping the Faith, 149.
} 
essayists also tended to portray a "Catholicism of clear and clean definition." 44 Nor did ordinary Catholics seem to question the authority of the church and its representatives, the priests, brothers and sisters. Questions were not needed, only devotion. ${ }^{45}$ The pervasive nature of this culture is evident in the reaction of leading Catholic scholars such as Philip Gleason who testified that Catholics experienced both "profound shock" and an "identity crisis" when this culture collapsed. $^{46}$

The contention that the Neo-Thomistic classicism formed the dominant Catholic culture is further strengthened once the role of 'elites' in forming a sense of identity within a community is considered. Gary R. Miedema contends that in any given society the elite social class "constructs" identities to serve their own interests, constructions that are not limited to religion, but encompass any public identity including that of a nation. ${ }^{47}$ According to cultural theorist, Raymond Williams, "in any given society, in any period, there is a central system of practices, meanings and values, which can properly be called dominant and effective," and which are "not merely abstract but which are organized and lived." 48 Public symbols and rituals were important "tools of cultural formation and maintenance" 49 that helped "shape personal and collective identities." 50 These 'tools' also assumed a "cognitive role, rendering intelligible society and social relationships, serving to organize people's knowledge of the past and present and their capacity to imagine the future." ${ }^{, 51}$ Understood in these terms, Catholics were subject to these 'tools of cultural formation' when they went to church, when they attended a Catholic school, and when they participated in public events like 'Catechetical Days.' All of these 'public symbols and rituals' reinforced the dominance of Catholic Neo-Thomistic classicism. Schools, as public institutions, played a key role in establishing this dominance as recent studies of Ontario education have indicated. ${ }^{52}$

Among the many factors that led to the shattering of this classicist culture and therefore the fundamental shift in Catholic secondary education was the impact of secularism on the Catholic community. ${ }^{53}$ For centuries Christianity had formed the cultural hegemony in North America where the dominant culture remained fundamentally Christian even into the $1960 \mathrm{~s} .{ }^{54}$ For example,

\footnotetext{
${ }^{44}$ McNamara, Conscience First, 18

${ }^{45}$ McNamara, Conscience First, 29. This type of Catholicism has been termed "devotional Catholicism", a "firm and long-standing tradition." It is an expression of Catholic classism and the Catholic mind.

${ }^{46}$ Philip Gleason, "In Search of Unity: American Catholic Thought 1920-1960," The Catholic Historical Review Vol 65 No. 2 (1979): 186-87, http://www.jstor.org/stable/25020551

${ }^{47}$ Gary R. Miedema, For Canada's Sake: Public Religion, Centennial Celebrations, and the Re-making of Canada in the 1960s (Montreal: McGill-Queen's University Press, 2005), 7-8.

${ }^{48}$ Raymond Williams, Problems in Materialism and Culture: Selected Essays (London: Verso, 1980), 38.

${ }^{49}$ According to Miedema, there is a growing consensus among scholars, including sociologists, anthropologists, cultural theorists and historians, that public rituals and symbolism need to be understood as important cultural tools of dominance. Miedema, For Canada's Sake, 9.

${ }^{50}$ Gary R. Miedema, For Canada's Sake, 10.

${ }^{51}$ Steven Lukes, "Political Ritual and Social Integration," Sociology (Oxford) 9 (1975): 301, doi:10:1177/003803857500900205.

${ }^{52}$ Bruce Curtis, Building the Educational State: Canada West, 1836-1871 (London: Althouse Press, 1988), 13-17.

${ }^{53}$ In this paper secularization is defined as a process that "has weakened traditional religious faith, affiliations and practices along with insisting upon a stronger distinction/separation between religion and education." Secular values are understood as being different from Catholic values, which are based on a world view centred on God and Christian belief. James Arthur, "The de-Catholicising of the curriculum in English Catholic Schools" in International Studies in Catholic Education Volume 5, Number 1 (2013): 83-98, DOI:10.1111/milt.12000.

${ }^{54}$ Miedema, For Canada's Sake, 22.
} 
as late as $1965,83 \%$ of Canadian Catholics still went to church on a regular basis. ${ }^{55}$ In Ontario public schools, religion was a mandatory course until $1969 .{ }^{56}$ Christianity also continued to hold a prominent place as religious symbols and rituals still assumed a significant public role well into the 1960s. Throughout the decade the Canadian Parliament opened with the Speaker of the House reciting non-sectarian Christian prayers. ${ }^{57}$ When the new Canadian flag was adopted in 1965, the ceremony included a prayer service at the request of Prime Minister Lester B. Pearson. ${ }^{58}$ A nondenominational prayer service was also a part of the Centennial celebrations on Parliament Hill. ${ }^{59}$ Yet because of the increasing cultural pluralism in Canada and the United States during the postwar years, this Christian hegemony was undermined as it became evident that North American culture was changing and that the general population was more open to ethnic diversity, especially after the horrors of World War II and the Holocaust. ${ }^{60}$

Cities became more cosmopolitan as illustrated in Toronto where by 1961 immigrants or new Canadians represented $25.2 \%$ of the population. ${ }^{61}$ As Canadians became more tolerant and open to cultural diversity, their understanding of democratic and liberal values underwent a major shift. For decades Canadians assumed that these values were intrinsically connected to their Christian beliefs, that Christianity gave birth to these values, and therefore it was essential to maintain the dominant Christian culture of Canada. After the war, however, with increased exposure to different religions and cultures, this fundamental connection was broken. Liberal and democratic values continued to be cherished, but most Canadians no longer held that they were primarily 'Christian values,' but that peoples of other cultures and religions could share them. ${ }^{62}$ It was during the 1960s, the hinge decade between the more religious 1940s and 1950s and the more secular 1950s and 1960s, that the Christian hegemony in North America collapsed. Ironically, the demise of this fundamentally Protestant hegemony resulted in the Catholic classicist culture becoming more vulnerable to secularism. As one of Canada's most distinguished Catholic scholars, John T. McIlhone, noted in 1966: "Sixty years ago, no Catholic would have deplored the disappearance of the Protestant. Then, all sects regarded each other with distrust-but the one thing they held in common was their assessment of values. Protestant, Catholic, and Jew generally agreed on what was right and what was wrong. But today, this is not the case." ${ }^{63}$

Aside from cultural pluralism, another major factor in the secularization process was the unprecedented period of prosperity after World War II and the subsequent impact of the so-called

\footnotetext{
${ }_{55}^{55}$ Miedema, For Canada's Sake, 35.

${ }^{56}$ John Webster Grant, The Church in the Canadian Era (Vancouver: Regent College Publishing, 1998), 179.

${ }_{58}^{57}$ Miedema, For Canada's Sake, 21.

${ }^{58}$ Miedema, For Canada's Sake, 20.

${ }^{59}$ Miedema, For Canada's Sake, 20.

${ }^{60}$ Even by 1941 Canadians of British descent no longer formed the majority. Miedema, For Canada's Sake, 27. With Canada playing an active role in the United Nations and with the increasing globalization, Canadians became somewhat more internationalist in their attitudes, leading to more tolerance towards ethnic minorities. Miedema, For Canada's Sake, 30. In 1956-57, this new attitude was evident in the Canadian government's response to Soviet suppression of a popular revolt in Hungary when thousands of Hungarians were admitted to Canada. J.L.

Granatstein, Canada 1957-1967: The Years of Uncertainty and Innovation (Toronto: McClelland and Stewart, 1986), 4.

${ }^{61}$ Granatstein, Canada 1957-1967, 6. Bryan D. Palmer, Canada's 1960s: The Ironies of Identity in a Rebellious Era (Toronto: University of Toronto Press, 2009), 421.

${ }^{62}$ Miedema, For Canada's Sake, 38-39.

${ }^{63}$ John T. McIlhone, "How necessary is the Catholic School in Contemporary Society?", Christian Education: Selections of Significance (The Catholic School Journal, March 1967), 3. This article was the conclusion of a longer address presented to the English Catholic Education Association of Ontario on April 12, 1966. G.E. Carter, Religious Education, B19-F2. London Archives.
} 
baby boomer generation on society, which contributed to the major shift in terms of values as a more affluent and consumer-oriented society developed. Catholics also participated in the benefits of the postwar prosperity and gradually assimilated into the dominant secular culture that was emerging in North America as the Christian cultural hegemony collapsed. ${ }^{64}$ Anxious to enjoy what they considered a 'normal' life, after years of economic depression and then war, Canadians and Americans 'settled down' and raised large families. ${ }^{65}$ In order to accommodate their needs, suburbs expanded in most cities across North America. ${ }^{66}$ Most parents wanted to provide their children with the consumer goods that they themselves never possessed in the pre-war years. A general consensus exists among scholars that the values of consumerism and affluence, in other words a desire for material goods, gradually became dominant. ${ }^{67}$ By the 1950 s North American society had also become child-centred "to an unparalleled degree" as parents made their children the centre of their lives as they searched for a normal and stable life. ${ }^{68}$ These children grew up convinced that "society was designed" for them with individual fulfillment as one of their major life-goals. ${ }^{69}$ Individualism became a major feature of this affluent, pluralistic and secular society. Individuals, not the Church nor any other entity, determined their own values and personal meaning.

Another essential development of this period that contributed to the fundamental shift in Catholic secondary religious education was therefore the changing social values. People became much more concerned with race relations and with the human rights, as demonstrated by the United Nations Declaration on Human Rights. Gradually human rights, and therefore individual rights, became a major focus, culminating in the civil rights movement in the 1960s. As well, people had become convinced of the fragility of democracy itself because of the rise of totalitarian states during the 1930s and the fear of communism after the war. A democratic society needed to be both anti-authoritarian and tolerant. When the civil rights movement gathered steam in the mid1950 s, the youth were more inclined to be critical of their own society and government-especially after the assassination of John F. Kennedy in 1963. When the international situation took a turn for the worse in the 1960s, with the Cuban Missile Crisis in 1963, the invasion of Dominican Republic in 1965, and the escalation in American involvement in Vietnam, young people blamed

\footnotetext{
${ }^{64}$ This assimilation has been well documented. Philip Gleason, Keeping the Faith: American Catholicism Past and Present (Notre Dame: University of Notre Dame Press, 1987), 31-32.

${ }^{65}$ In Ontario, for example, the fertility rate in 1936 was 2.2 children. By 1961 there were nearly 4 children for each woman of child bearing years. R.D. Gidney, From Hope to Harris: The Reshaping of Ontario Schools (Toronto: University of Toronto Press, 1999), 26. The increase in the number of school-aged children was evident in the enrolment figures. Whereas the population of Ontario doubled between 1946 and 196, the number of elementary aged children increased by $116 \%$ and high school aged children by $141 \%$ (more students were staying in high school beyond the age of 15 unlike before the war). Gidney, From Hope to Harris, 27. By 1966, almost 5 million people were in school across Canada, double the figure 14 years earlier. Doug Owram, Born at the Right Time: A History of the Baby Boom Generation (Toronto: University of Toronto Press, 1997), 114.

${ }^{66}$ For example, the population of Scarborough, a suburb of Toronto, increased dramatically. In 1941, the population was 24,000; by 1971, 343,000. Other Ontario urban centres experienced similar increases in population. Gidney, From Hope to Harris, 26.

${ }^{67}$ McLeod, "Reflections," 463.

${ }^{68}$ The ultimate result of this search was the 'baby boom' as people took advantage of a lengthy period of prosperity to find permanent employment and therefore the financial resources to have large families. The fertility rate in 1936 was 2.2 children. By 1961 there were nearly 4 children for each woman of child bearing years. Robert Douglas Gidney. From Hope to Harris: The Reshaping of Ontario Schools, (Toronto, 1999), 26-27.

${ }^{69}$ Doug Owram. Born at the Right Time: A History of the Baby Boom Generation, (Toronto: University of Toronto Press, 1996) p. 135. The baby boom also resulted in a building spree as more schools were needed to accommodate the increasing number of students. For example, whereas the overall population of Ontario increased $50 \%$ between 1946 and 1961, elementary enrolment increased 116 \% and high school, 141 \%. Gidney, From Hope to Harris, 27.
} 
the government and took to the streets in protest. A "crisis of authority" marked the 1960s, resulting in a proliferation of protest movements, youth radicalism, and the sexual revolution, as the dominant social conservative mores and the institution of marriage itself were challenged as never before. For the Church, the increasing secularization of society, and the accompanying changing social values, was ultimately expressed in the "religious crisis" of the 1960s - a crisis shared by all Christian dominations - in which many Catholics not only questioned Church authority, but rejected it altogether ${ }^{70}$ as almost an entire generation abandoned regular religious practice and thousands left the religious orders. ${ }^{71}$

Another major factor influencing the fundamental shift in Catholic secondary religious education was the impact of the changing social values on educational systems across North America, including that of Ontario. The new emphasis on human rights and democracy influenced curriculum development in both Canada and the United States. In the 1950s, three themes began to appear in the textbooks: democracy, tolerance, and inclusiveness. ${ }^{72}$ In the late $1950 \mathrm{~s}$, the philosophy of John Dewey once again become popular, and even though his philosophy was never totally implemented in Ontario, nor properly understood, some of its basic principles became integrated in the curriculum: child-centred learning, anti-authoritarian teaching and belief in education as a means for social reform. ${ }^{73}$ Reformers demanded a more child-centred curriculum that focussed on enhancing the students' self-esteem, that emphasized the needs and interests of the child, and that allowed for a variety of teaching methods. Self-directed learning was also advocated. Schools were to be vehicles of social change. The reformers insisted that "the whole child goes to school" and thus the curriculum must also consider the child's social and emotional needs. ${ }^{74}$ No longer could the curriculum be shaped only according to the academic needs of the student. Since the Catholic schools were essentially an integral part of the Ontario public school system, they could not but be affected by the growing demand for educational reforms.

This demand resulted in the monumental report on education in Ontario, the 1968 HallDennis Report, "Living and Learning," which provided the framework for the educational reforms that followed, and which influenced how religion was taught in Catholic high schools. ${ }^{75}$ Highly

\footnotetext{
${ }^{70}$ The rejection of this authority was directly connected to the Church's prohibition on contraceptives. According to L.W. Tentler, "trained as they were to obedience, most Catholics came gradually to a full sense of moral autonomy - a process nearly always connected to agonizing over contraception.” L.W. Tentler, Catholics and Contraception: An American History (Ithaca: Cornell University Press, 2004), 231. Catholic dissent became noticeable in the early 1950s when polling data indicated that $51 \%$ of Catholics disagreed with the Church's teaching, and did not consider using contraceptives as sinful. Tentler, Catholics and Contraception, 200. As Catholics became more assimilated into the secular culture, and as the Catholic classicist culture continued to crumble, most Catholics became more frustrated with the Church's position. By the mid-1960s, they expected the Church to allow them to use contraceptives. When Paul VI's encyclical, Humanae Vitae, upheld the prohibition, most Catholics were angry and ignored it. It became a "dead letter." In the final analysis, it was "individual authority that reigned supreme." Tentler, Catholics and Contraceptives, 3.

${ }^{71}$ The complexity of this religious crisis is aptly summarized in Callum G. Brown's "What was the Religious Crisis of the 1960s?", Journal of Religious History Volume 34, No. 4 (2010), doi. 10.1111/j.1467-9809.2010.00909.x.

${ }^{72}$ Owram, Born at the Right Time, 132.i

${ }^{73}$ Owram, Born at the Right Time, 126-127. The philosophy of Dewey will not be discussed here. His complex philosophy was not fully implemented in the United States and the manner in which it was actually received remains a topic of debate and controversy. It is suffice to mention that the new emphasis on "child-centred" and a "democratic" education can be traced to the progressive movement in education, epitomized by the works of Dewey.

${ }^{74}$ Gidney. From Hope to Harris, 31.

${ }^{75}$ Only the aspects of this report that influenced the fundamental shift in Catholic secondary education will be examined. This report was also the result of a reform process that began in the Ministry of Education, featuring a power struggle between reformers and traditionalists who were mainly high school administrators. The reformers
} 
critical of this system, emphasizing the "outdated curriculum," the "regimental organization," and the "mistaken aims of education," 76 the document called for a more child-centred education that focused on the social needs of the child and where:

The child will progress from year to year without the hazards and frustration of failure. His natural curiosity and initiative must be recognized and developed. New methods of assessment and promotion must be devised. Counselling by competent persons should be an integral part of the educational process. The atmosphere within the class room must be positive and encouraging. The fixed positions of pupil and teacher, the insistence on silence, and the punitive approach must give way to a more relaxed teacher-pupil relationship which will encourage discussion, inquiry, and experimentation, and enhance the dignity of the individual. ${ }^{77}$

Throughout the document the importance of freedom, democracy and the 'search for truth' are also major themes: "Freedom to search for truth at every educational level is one of the stoutest ramparts of a free society, and this defence we must never yield if we are to protect our way of life."78 Even the structure of the school needed to be changed in order to allow the students to learn in a less restrictive environment. ${ }^{79}$ The report, with its focus on democracy and child-centred education, reflected the values of a child-centred society increasingly concerned with individual fulfillment. ${ }^{80}$ Furthermore, the evidence indicates that Catholic educators shared these values as they were well-represented on the provincial committee that issued the report ${ }^{81}$. Catholics in general also shared in these values since they were subject to a natural "secularization of consciousness" whereby Catholic students and teachers unconsciously adopted the secular values of the society in which they lived. ${ }^{82}$

\section{Vatican II and the Declaration on Christian Education}

One of the major factors contributing to the fundamental shift in Catholic secondary religious education was the overall impact of Vatican II, which began a process of renewal within the Church in order to adapt it to the changing modern world. A key aspect of this renewal was the abandonment of strict Neo-Thomism as the official philosophy of the Church. Vatican II was therefore not only characterized by a new openness to the modern world, but by the rehabilitation of the critics of strict Neo-Thomism within the Church whose ideas were encapsulated by the term

\footnotetext{
won, and for the first time, educational reforms would affect both elementary and high schools (The high school curriculum had changed very little since 1871 except for the addition of some except for the introduction of commercial and vocational courses.) Gidney, From Hope to Harris, 30.

${ }^{76}$ Living and Learning: The Report of the Provincial Committee on Aims and Objectives of Education in the Schools of Ontario, 1968. p. 9

${ }^{77}$ Living and Learning, 16

${ }^{78}$ Living and Learning, 2.

${ }^{79}$ Living and Learning, 22.

${ }^{80}$ Once it was released, it was clear that the report reflected these values. The reception was overwhelmingly positive and within 16 months 60,000 copies were sold. Gidney. From Hope to Harris, 75.

${ }^{81}$ Living and Learning, 4-7. The Co-Chair of the committee, E.M. Hall, was the former Chair of the St. Paul's Separate District, Saskatoon.

${ }^{82}$ In this context, secular values are understood as being different from Catholic values, which are based on a world view centred on God and Christian belief. James Arthur, "Secularisation, secularism and Catholic Education: the challenges" in International Studies in Catholic Education Volume 1, Number 2 (2009): 228-239, DOI: $10.1080 / 19422530138226$.
} 
the "new theology." 83 This rehabilitation is central not only to understanding what happened at Vatican II, but also to understanding the fundamental shift in secondary religious education as educators adopted the concepts of the new theology.

Using the historical-criticism method, the 'new theologians' argued that there was not just one immutable and perennial Christian philosophy, but rather that a plurality of philosophies existed. ${ }^{84}$ Moreover, they contended that Church doctrine was developmental, and therefore was subject to historical change since they also held that Revelation did not end with the death of the last apostle. Thus, Church tradition was a 'living tradition', which developed and changed over the centuries. The new theologians also adopted a subjective approach to religious belief and to discovering God, emphasizing the relationship between the individual believer and God, arguing that human beings could only be content with God because of the "inner drives" of the human being and the dynamics of the mind. ${ }^{85}$ Thus, the new theologians rejected the strict Neo-Thomist contention that knowledge of God could only be obtained through the objectivity of the intellect. A major thrust of the new theology was also to provide "spiritual nourishment" to ordinary believers from the 'great mysteries of the faith' and from the original sources of Christianity, the bible, the Fathers and the liturgy. ${ }^{86}$ For the new theologians Christianity was a "living faith" not isolated from the modern world, but intimately involved in the everyday lives and concerns of the individual believers. ${ }^{87}$ According to Mettepenningen, the Second Vatican Council "ultimately appropriated the central features of the ambitions of the new theology, "88 which is evident in many of the conciliar documents. ${ }^{89}$

\footnotetext{
${ }^{83}$ The history of the development of the 'new theology' is a complex one. Even the term is contentious. Some of the leading so-called new theologians disliked the term, arguing that what they proposed was not new. Yves Congar referred to it as an "imaginary monster", and Henri de Lubac never considered himself as a 'new theologian'. As early as 1946, de Lubac informed his Jesuit Superior that he never promoted any new theology, and in a interview years after Vatican II, commented that it was a myth. Jurgen Mettepenningen, Nouvelle Theologie-New Theology: Inheritor of Modernism, Precursor of Vatican II (London: T\&T Clark International, 2010), 101.

${ }^{84}$ The new theologians benefitted from the existing pluralism within Neo-Thomism. For example, a leading Thomist, Etienne Gilson, discovered that such a pluralism existed even St. Aquinas' day. Gilson defended his position by publishing brilliant studies on St. Bonaventure, St. Augustine, St. Thomas, and John Duns Scotus. Their philosophies were "highly diverse", allowing Gilson to conclude that a "radical philosophical pluralism" existed in the Middle Ages. Gerald A. McCool, From Unity to Pluralism: The Internal Evolution of Thomism (New York: Fordham University Press, 2002), 171.

${ }^{85}$ In terms of subjectivity, the new theologians were indebted to Maurice Blondel, particularly his monumental 1893 L'Action. William Porter, "Twentieth-Century Catholic Theology and the Triumph of Maurice Bondel" Communio: International Catholic Review 33 Spring, (2011): 110, http://www.communio-icr.com.

${ }^{86}$ Mettepenningen, Nouvelle Theologie, 31.

${ }^{87}$ It is important here to note that the development of the new theology was a complicated one and cannot be divorced from overall context of changes that were occurring within the Church during the twentieth century. Mettepenningen has identified several trends that influenced the new theology and therefore Vatican II: The Church understood as a community of believer, "the people of God", and not only the institutional hierarchy; a more Christoriented spirituality; more interest in the historical Jesus; increasing concern for the individual believer and therefore social action; the growing popularity of kereygmatic theology, focusing on spirituality and mysticism; and the liturgical movement with its emphasis on a greater role for the laity. Mettepenningen, Nouvelle Theologie, 27-29.

${ }^{88}$ Mettepenningen. Nouvelle Theologie, 36.

${ }^{89}$ The dogmatic constitution, Dei Verbum, which emphasized the importance of the sources of the faith, had "definite echoes" of the new theology. The constitution on Divine Revelation also reflected the influence of the new theology, and the pastoral constitution, Gaudium et Spes, highlighted that theology should "pursue a profound understanding of revealed truth" and "at the same time it should not neglect close contact with its own time that it may be able to
} 
What was also noticeable in all of the documents was the change in the style of discourse which had a major impact on the nature of secondary religious education after Vatican II. The preVatican II style, dominated by words of authority, of intimidation, threat, condemnation, and punishment, was abandoned. ${ }^{90}$ These "power words" were replaced with words implying a more reciprocal relationship such as dialogue, partnership, friendship, co-operation, and charism. ${ }^{91} \mathrm{~A}$ more pastoral language was used. Vatican II "radically altered" the legislative and judicial model that had dominated the ecumenical councils ever since Nicaea, replacing it with a model based on "persuasion and invitation - a monumental shift." 92 It represented a return to the literary genre of the ancient Romans and adopted by the Church Fathers, the panegyric. The purpose of this genre was "not so much to clarify concepts as to heighten appreciation for a person, an event, or an institution and to excite emulation of an ideal." 93 Its goal was to achieve the internal assent of the individual and not to impose a mode of thinking. What was significant was the "inner transformation" of values. According to O'Malley, if the "special characteristics" of Vatican II were ranked, this change in discourse could perhaps be the highest ranked. ${ }^{94}$

This style of discourse did not merely involve a new vocabulary, but embodied the "ultimate expression of meaning...it does not adorn meaning, but is meaning." 95 In order to clarify the importance of the words in terms of meaning, O'Malley organizes them into five categories: "horizontal-words" or "equality-words" such as the people of God, brothers and sisters, and collegiality; "words of reciprocity" such as cooperation, dialogue and collaboration; "humilitywords" such as pilgrim and servant; words of change such as development and progress; and "interiority-words" such as charism, joy, hope, and conscience. ${ }^{96}$ In a practical sense, this new style of discourse and the new model of authority that it represented was embodied in the principle of subsidiarity according to which when there was a legitimate authority dealing with an issue, a superior authority did not interfere. ${ }^{97}$ Thus, this style of discourse expressed the meaning of what happened at Vatican II; a council that rejected the traditional model of authority within the church, that emphasized the inner transformation of the individual, and that accepted the fundamental aspects of the new theology.

\footnotetext{
help these men skilled in various disciplines to attain a better understanding of the faith." Mettepenningen, Nouvelle Theologie, 36, 143.

${ }^{90}$ Mettepenningen, Nouvelle Theologies, 45.

92 John W. O’Malley, What Happened at Vatican II (Cambridge: The Belknap Press of Harvard University Press, 2008), 11 .

${ }^{93}$ O'Malley, What Happened at Vatican II, 47.

${ }^{94} \mathrm{O}$ 'Malley, What Happened at Vatican II, 43.

${ }^{95} \mathrm{O}$ 'Malley, What Happened at Vatican II, 49.

${ }^{96}$ O'Malley, What Happened at Vatican II, 49-51.

${ }^{97}$ W. M. Higgins and D.R. Letson, My Father's Business: A Biography of His Eminence G. Emmett Carter (Toronto: MacMillan, 1990), 76. This is not to argue that there was an easy, simplistic shift in power from the curia to the bishops. The distribution of authority was a major area of contention at the council that extended beyond the relationship between the bishops and the Curia to include the laity, especially since Lumen Gentium referred to the church as "the people of God". Nor did not mean that the "superior authorities' always respect this principle during and after the council. For example, in 1974, Carter, frustrated that the Congregation for the Doctrine of the Faith, the new title for the Holy Office, was interfering with the work of the International Commission on English in the Liturgy, commented: "the Holy Office...may have changed its name but does not appear to have changed its spots."
} 
All of the Vatican II documents reflected this new style of discourse to varying degrees. ${ }^{98}$ At the time commentators recognized the coherence that permeated the documents in terms of this discourse and the principles that it expressed. This coherence was a deliberate act to assure the intertextual nature of the documents, which were frequently revised in order to maintain this coherence. A vague term, the "spirit of the council" was used to describe an "overriding vision that transcended the particularities of the documents." "Thus, in terms of interpreting the different documents, this coherence needs to be considered. Furthermore, the overriding importance of the four constitutions was also recognized at the council, and the bishops at their 1985 Synod declared that these constitutions provided the "orientation" for all of the documents which formed a "coherent corpus.", 100

Thus, the Declaration on Christian Education must be understood in terms of the Vatican II constitutions and the overall influence of the new theology and the meaning of the new style of discourse, especially in order to understand its impact on the fundamental shift in secondary religious education. Of particular importance in terms of education is the emphasis on the role of the laity in the constitutions. For example, Lumen Gentium, the dogmatic constitution, emphasizes the dignity of the laity and its "exalted duty of working for the ever greater spread of the divine plan of salvation to all men." "In article 14 of Sacrosanctum Concilium, the constitution on sacred liturgy, the laity is encouraged to participate more in the liturgy, to assume a more active role worthy of "a chosen race, a royal priesthood, a holy nation, a redeemed people (1 Pet. 2:9, 4-5).",102 In Gaudium Et Spes, the pastoral constitution, an entire chapter is entitled 'The Dignity of the Human Person.' The influence of these constitutions is evident in the Declaration's positive attitude towards the laity and its lack of emphasis on the sinful nature of humanity. Indeed, in the preface of the Declaration, an increasing awareness of the 'dignity and position' of the human person is emphasized. ${ }^{103}$

The new style of discourse is also evident throughout the Declaration, reflecting the bishops' clear intention in terms of meaning in certain aspects of the document. Nowhere to be found are the 'power-words' that emphasize threats, punishments, and obedience. The traditional 'legislative and judicial' model of authority has been abandoned. The rights of the individual believer are instead emphasized. For example, unlike with Pius XI's 1929 encyclical, On Christian Education, in which the Church's supreme role in education is emphasized, its role in the Declaration is understood as in partnership with both the school and the parents. ${ }^{104}$ No longer are parents ordered to send their children to Catholic schools, but rather must enjoy "the fullest liberty in their choice of school." 105 Here the principle of subsidiarity is invoked with the parents recognized as an authentic authority. The "public authority" must therefore provide the necessary funds to Catholic schools so that parents are "truly free" to select schools for their children.",106

\footnotetext{
98 This style of discourse was "best exemplified" in the four constitutions. This "new' style was different from the style of previous councils, yet it nonetheless was not evenly used in the documents since its use was controversial and challenged by some council participants. O'Malley, What Happened at Vatican II, 46.

${ }^{99}$ O'Malley, What Happened at Vatican II, 52.

100 O'Malley, What Happened at Vatican II, 2-3.

${ }^{101}$ Austin Flannery, Vatican Council II: The Conciliar and Post Conciliar Documents, Volume One. (New York: Costello Publishing Company 1998), 391.

${ }^{102}$ Flannery, Vatican Council II, 7-8.

${ }^{103}$ Flannery, Vatican Council II, 725.

${ }^{104}$ Flannery, Vatican Council II, 730-732.

${ }^{105}$ Flannery, Vatican Council II, 731.

${ }^{106}$ Flannery, Vatican Council II, 731.
} 
The lack of 'power-words' also indicated that the church was somewhat humbler, more willing to admit that it did not yet know everything and that it was not the inheritor of an immutable 'deposit' of the faith that it needed to defend and protect: it accepted the concept of mystery. Students therefore should be introduced to "the knowledge of the mystery of salvation" and contribute to "the growth the "Mystical Body.",107

Absent as well is the strict Neo-Thomism that permeated Pius XI's encyclical. Thomas Aquinas is only mentioned once as an example of how to approach "new and current" scientific questions by maintaining "the harmony of faith and science." the method of St. Thomas that is emphasized, not his philosophy - a method of "doing philosophy" as Etienne Gilson emphasized - which involved research and inquiry. Such a method was appropriate since the concept of immutable doctrine had also been abandoned. The Declaration clearly states that the role of the "Faculties of Sacred Sciences" is to "promote research in the different fields of sacred learning" and "to ensure that an ever-growing understanding of sacred revelation be achieved, that the inheritance of Christian wisdom handed down by former generations be more fully appreciated... and that the questions arising from the development of thought be duly solved." 109 Thus, the Declaration embodied the new theology, in particular concerning the role of tradition in the church - the concept of a living tradition.

The style of discourse in the Declaration also indicated another major shift away from the pure objectivity of strict Neo-Thomism. Words of 'inner transformation' are throughout the document. The subjectivity of the individual believer is emphasized. Thus, when the Declaration discussed the parents' right to select a school for their children, it was "in accordance with their conscience." ${ }^{110}$ Secular governments also had to provide Catholic schools in order to preserve "the liberty of conscience." "111 The students also had the right to "be stimulated to make sound moral judgments based on a well-formed conscience and to put them into practice with a sense of personal commitment." 112 They also should learn "how to give witness to the hope that is in them." Even the right to a Christian education is justified, not by the authority of the Church, but by the 'inner transformation' of individuals reborn "in water and the Holy Spirit" who are "children of God." 113 They should be trained "to live their lives in the new self, justified and sanctified through the truth." 114 The purpose of catechetical instruction is not defined in terms of objective understanding of Church doctrine or the shaping of the will, but instead as a process that "develops a life in harmony with the spirit of Christ, stimulates a conscious and fervent participation in the liturgical mystery and encourages men to take an active part in the apostolate." ${ }^{, 15}$ With such an emphasis on inner spirituality, the source of stimulation and encouragement, the role of the church is one of guidance and invitation, not one of legislation or judgement.

Thus, the Declaration reflected the new style of discourse, the new theology, and the new emphasis on the principle of subsidiarity, yet it also reflected an effort to maintain a balance between these reforms and traditional Catholic education. For example, Pius XI's 1929 encyclical,

\footnotetext{
${ }^{107}$ Flannery, Vatican Council II, 728.

${ }^{108}$ Flannery, Vatican Council II, 735-736.

${ }^{109}$ Flannery, Vatican Council II, 736.

${ }^{110}$ Flannery, Vatican Council II, 731.

${ }^{111}$ Flannery, Vatican Council II, 733.

${ }^{112}$ Flannery, Vatican Council II, 727.

${ }^{113}$ Flannery, Vatican Council II, 727.

${ }^{114}$ Flannery, Vatican Council II, 728.

${ }^{115}$ Flannery, Vatican Council II, 730.
} 
Divini Illius Magistri was quoted ten times in the notes of the Declaration. ${ }^{116}$ Thus, along with the new style and the subsequent new meaning, it was also the bishops' intention to defend and promote fundamental Catholic educational principles which were long-held positions of the church, which, in other words, were part of the 'living tradition.' For example, the Declaration recognized the need for more progressive forms of education, yet was also critical of certain progressive tendencies. It thus adhered to the Church's traditional opposition to the "current tendencies" in education that made social progress "the sole yard-stick of the educational system." "The Church took a stand against the tendency in which "learning, fact-finding and instruction are all too easily confused with the whole human education."118 Nine of the twelve articles of the Declaration discuss these tendencies. ${ }^{119}$ Furthermore, the Declaration recognized the need to educate all children no matter their intellectual ability, ${ }^{120}$ exhorting those who were "in control of education to make it their care to ensure that young people are never deprived of this sacred right," ${ }^{121}$ while at the same time insisting that schools could still maintain overall high academic standards in all subjects, including religion. Parents were therefore encouraged to demand that their children receive a religious education "to a degree that is abreast of their development in secular subjects." 122 Thus, the Church had not changed in its support for certain traditional principles of education. What had changed was the manner in which the Church defended and promoted them as the changes in the style of discourse indicated.

Despite its many positive attributes, the Declaration remained however a deeply flawed document. It lacked substance. O'Malley emphasizes that in terms of determining meaning the new style of discourse and the document content must both be considered in unison. The style of discourse gave meaning to the content. With the Declaration, however, the problem is the lack of content. This problem is the result of the underlying flaw of the Declaration: the lack of clarity concerning the relationship between education and the modern world. Superficially, the Declaration expressed a "new attitude of openness to the world." ${ }^{\text {"123 }}$ Article 8 on Catholic schools, the 'heart' of the Declaration, ${ }^{124}$ stated that the Catholic school must be "open...to the situation of the contemporary world." What was meant by openness remained, however, vague. Educators were provided with little direction as to how Catholic education should adapt to the modern world. This was in part due to the tensions between the conservative and progressive forces within the Church. One of the most controversial issues involved the degree of importance that should be accorded to Thomas Aquinas whose philosophy had dominated Catholic education since Leo XIII's Aeterni Patris. ${ }^{125}$ The Declaration therefore had a "tortured history" since it underwent several revisions, and just before the bishops voted, criticism of the document was still "widespread and wide ranging." 126 The bishops almost rejected the document - a fate avoided for two reasons: the obvious need to address the problems of education and the decision to deal with

\footnotetext{
116 Johannes Pohlechneider, Johannes, "Declaration on Christian Education." Commentary on the Documents of Vatican II, edited by Herbert Vorgrimler, 1-48, (Montreal: Palm Publishers, 1969), 13.

${ }^{117}$ Pohlechneider, "Declaration on Christian Education," 15.

118 Pohlechneider, "Declaration on Christian Education," 15.

${ }^{119}$ Pohlechneider, "Declaration on Christian Education," 15.

${ }^{120}$ Pohlechneider, "Declaration on Christian Education," 1.9

${ }^{121}$ Flannery, Vatican Council II, 727.

${ }^{122}$ Flannery, Vatican II, 732.

${ }^{123}$ Pohlechneider, "Declaration on Christian Education," 13.

${ }^{124}$ Pohlechneider, "Declaration on Christian Education," 29.

125 O'Malley, What Happened at Vatican II, 270.

${ }^{126}$ O'Malley, What Happened at Vatican II, 269-270.
} 
these problems in the future. ${ }^{127}$ Thus it is stated in the introduction of the Declaration: "Accordingly the sacred Synod hereby promulgates some fundamental principles of Christian education, especially in regard to schools. These principles should be more fully developed by a special postconciliar commission and should be adapted to different local circumstances by episcopal conferences." 128 The overall weakness of the document was also indicated by the use of the term 'declaration' since it was reserved for topics that proved too controversial to be formal decrees. ${ }^{129}$ Even one of principle authors of the Declaration, Father Dezza, stated that it was marked by a "generality" caused by the complexity of the issues. ${ }^{130}$ Cardinal Ratzinger, later Pope Benedict XVI, also commented in 1966 that the Declaration was a weak document, and that "the text wasn't treated by the council fathers with any special affection." ${ }^{\prime 31}$ Bishop Emmett Carter agreed with this overall assessment, contending that the document brought "some clarification, if only to establish that the church has not changed its traditional positions." 132 The weakness of the Declaration is most noticeable in the lack of vision. It failed in the ultimate purpose of the panegyric literary genre: it failed to excite the 'emulation of an ideal.' Carter highlighted this failure when he commented after Vatican II that the Declaration "didn't speak to me, or make me want to shout "This thing is marvellous." 133 Thus, the failure of the Declaration as a definitive statement on education had significant consequences for secondary religious education.

\section{Secondary Religious Education in Ontario After Vatican II}

It was after Vatican II that the fundamental shift in Catholic secondary religious education occurred with significant changes in both how religion was taught and understood. Strict NeoThomism was rejected, and thus teachers adopted the new theology concepts when teaching religion. Critical to this shift was the extent to which certain essential secular and Catholic values were very similar during the long sixties. Both secular society and the Church emphasized the rights of the individual, emphasizing subjectivity, inner transformation, and the 'liberty of conscience.' The Church thus became much more open minded in terms of pedagogy, accepting new progressive methods. Both secular society and the Church also emphasized the importance of democratic rights with the Church, albeit not a democratic institution, adopting the policy of subsidiarity, which involved some decentralization of power much like what took place in the Ontario Ministry of Education. This new sense of 'democracy' was also evident with the style of discourse emphasizing "equality-words" such as the people of God, brothers and sisters, and collegiality. Another shared value involved the importance of pursuing social justice and therefore the common good. Thus, Catholic secondary religious education was shaped by the considerable infusion of values shared with the existing secular society.

With the rejection of the traditional rote method of memorization and of the mandated strict Neo-Thomism, this infusion of values is evident in the significant changes in pedagogy. Classroom instruction was more student-centred as small group and class discussions became far more

\footnotetext{
${ }^{127}$ Mauro Velati, "Completing the Conciliar Agenda." History of Vatican II: Volume V, edited by Giuseppe Alberigo, (Maryknoll, NY: Orbis, 1995), 229-30.

${ }^{128}$ Flannery, Vatican Council II, 726.

${ }^{129}$ Giuseppe Alberigo, A Brief History of Vatican II. Maryknoll, NY: Orbis, 2006), 103.

${ }^{130}$ Velati, "Completing the Conciliar Agenda," 230.

${ }^{131}$ Don Briel, 2008. "The Declaration on Christian Education, Gravissimum Educationis." Vatican II: Renewal within Tradition, edited by Matthew L. Lamb and Matthew Leverin, \#. (Oxford: Oxford University Press, 2008), 389.

${ }^{132}$ Higgins and Letson, My Father's Business, 89.

${ }^{133}$ Higgins and Letson, My Father's Business, 88.
} 
common. ${ }^{134}$ The learner's subjective, personal experience also became central to the learning process, and thus educators were encouraged to instill Christian values and morals in the students, which was not a traditional focus. ${ }^{135}$ For example, in a major 1974 report from the Canadian Catholic Trustees' Association, the "urgency of developing our moral capacity" was emphasized in order to cope with an "increasingly complex" society that would demand that students make the proper moral choices. ${ }^{136}$ Even the Bishop of London, Emmett Carter, an acknowledged expert in education and who previously advocated the critical importance of knowing Church doctrine, stated in a 1968 letter to the school board's religion consultant that he was "convinced that religion, anywhere below university level, is above all a contact with Christian values...I am of the opinion that we should move towards this and perhaps divorce ourselves, at least for a time, from the academic aspects." $" 137$

Attention was also now given to the individual's 'real life experience' as religion was taught from a social perspective. In many schools, religion was now referred to as "Christian Living." For example, the 1971 Interim Curriculum Guidelines for Religious Education of the Toronto Metropolitan Separate School Board, reflected this new orientation as religious education was grouped with Family Life and Guidance \& Counselling under the title "Education for Christian Living." 138 At the beginning of the document, the Board's overall philosophy is articulated by referring to Karl Rahner, one of the most influential post-Vatican II theologians, who emphasized that the Christian message must be "based on "real-life experience and should not call for long explanations or the juggling of complicated concepts." 139 The 1967 Centennial Year Program for religious education, appropriately entitled "the People of God," also stressed the importance of lived experience, advocating that grade 9 and 10 students learn about the "living witness" of famous Catholic figures. ${ }^{140}$ In a series of major reports to the Sisters of St. Joseph, the individual's learning process was cited as the teacher's first priority, and should be conducted "within the context of his social relationship" and that the teacher needs to "assist the student to

\footnotetext{
134 This change was not limited to these dioceses. For example, in his 1973 report, Adolescent Catechesis in Canada, for the National Office of Religious Education, Wilfrid E. Murchland stated that one of the major shifts in religious education involved the change in pedagogy from the teacher as the expert, the "master of the mystery" who possess the truth, to the teacher as a partner in the learning process who dialogues with the students as they search for the truth. Adolescent Catechesis, 22-23. By the late 1970s small groups and class discussions also appear to have become the norm as indicated in the available course descriptions. In the 1975 Programme of Study for the Loretto Sisters of Toronto, class discussion was one of the major methods of instruction with the entire grade 9 course centered on seminar discussions. (Loretto Archives, Programmes of Study.) As well, in the Religious Education Manual of the Sisters of St. Joseph, Morrow Park, Toronto, emphasizes the importance of student-led discussion (Archives of the Sisters of St. Joseph, Toronto 205 2-2.

${ }^{135}$ Traditionally, the focus was on the accumulation of religious knowledge; moral development was not the primary concern of the school. For example, in a 1961 letter to the parents from St. Joseph's Morrow Park High School this was made clear: "...the "moral development" can only be effected by the Church and the Home; it is primarily their obligation." Sisters of St. Joseph, 205-2-2.

136 "Catholic Education from Principle to Practice in Catholic Schools", the Canadian Catholic Trustees' Association, Archives of the Archdiocese of Toronto, ED S004.12.

${ }^{137}$ Letter to Father Grannan. London Archives, B19 F26.

${ }^{138}$ It became quite common to have religion listed as a subject within a broader group, thereby indicating the new focus. For example, in the 1970's Loretto Abbey religion was in the Department of Social and Environmental Studies, Loretto Archives, Programmes of Study.

${ }^{139}$ Sisters of St. Joseph, 20D 5-4. Rahner was "probably the most influential figure in Catholic theology in the years immediately after Vatican II." Robert Royal, A Deeper Vision: The Catholic Intellectual Tradition in the Twentieth Century (San Francisco: Ignatius Press, 2015), 210.

${ }^{140}$ People of God, 3. London Diocese Archives, G.E. Carter School Boards Essex county Separate School B22-F2
} 
realize his potential and thus make his maximum contribution to physical and social change."141 In the Sub-Commission on Youth Report, a youth-led commission which was part of the Archdiocese of London Synod, an entire section was devoted to the "Youth as a Social Being Developing a Christian Conscience." ${ }^{142}$ At the 1968 Christian Curriculum Development Conference in Toronto Romeo Maione, an expert youth worker, focused on the same theme of education and social responsibility, in his key note address, "Who Educates the Youth?," concluding that "not just the teacher, but the school as an educational experience must become socially involved." ${ }^{143}$ In the long sixties, then, education had become student-centered with students given the opportunity to discuss and to ask questions, focusing as well on their lived experience within a secular society. This educational shift also occurred across Canada. Murchland in his national study referred to this fundamental shift as the "Copernican revolution in catechetics" with "the shift from the deductive, intellectualist, dogmatic, authoritarian approach to the inductive, experiential, personal, questioning-discovering, life-centered, freedomful approach." 144 Quoting Rahner, Murchland also highlighted that the individual's personal experience and inner transformation was key to high school religious education: "The theological problem today is to find the art of drawing religion out of man, not pumping it into him."145

The fundamental shift was also noticeable in terms of teacher resources. The mandated textbook series Quest for Happiness, was no longer sanctioned, replaced by a multitude of choices in textbooks. ${ }^{146}$ One of the most popular textbooks was the American publication, Hi Time, which took the form of a weekly magazine. Little attention was given to Church teachings with the different regular features focussing on the students' lived experience in a secular world. For example, one regular column was called "Straight Talk" where the columnist, Father Ken, responded to student letters about their personal issues. One such article discussed a student's mental health with the caption, "Hates Depression and Loneliness." Another regular feature, "Situation," dealt with typical teenage concerns in a story format. One article advised readers that reading about a non-Christian religion could lead to "a deeper understanding of your own beliefs." ${ }^{147}$ Hi-Time was typical of the textbooks available to teachers and reflected a fundamental shift in secondary religious education.

Such a shift was a much needed one as the traditional focus on Church doctrine to the exclusion of almost all other issues was excessive and out of touch with the modern world of the long sixties. However, it is argued here that the shift was too extreme, and that the long sixties was also a period of considerable confusion in secondary religious education. Part of the challenge was the new theology itself, which emphasized plurality, the search for truth, and the individual's inner transformation, rendering it difficult for educators to explain this theology to students. The teacher's task was much easier when it was only a matter of communicating immutable truths in a

\footnotetext{
141 "Reports of Sister Delegates to Educational Meetings 1963”, Sisters of St. Joseph, 200 4-5 Box 4.

${ }^{142}$ Sub-Commission on Youth, London Diocese Archives, DUA, Bishop E.G. Carter, Box 25, File 28. In London, Bishop Carter initiated the first diocesan synod focussing on the new Vatican II teachings. It lasted from 1965 to 1968.

${ }^{143}$ R. Maione, "Who Educates the Youth", 7. Sisters of St. Joseph, Lo0 6-4.

${ }^{144}$ Murchland, Adolescent Catechesis, 15.

${ }^{145}$ Murchland, Adolescent Catechesis, 23.

${ }^{146}$ Most course outlines listed several possible texts along with a series of films and filmstrips, indicating the availability of modern multi-media. Programmes of Study, Loretto Archives, 1975-1979.

${ }^{147}$ Hi-Time, Volume 19, Sept. 22 ${ }^{\text {nd }}, 1972$. London Archives B11-F16. This article also reflected the increasing interest in ecumenism that began with Vatican II. One regular feature of Hi-Time was "The Non-Christian Religions."
} 
mandated textbook to prepare students for standard exams. Nor were teachers given much guidance from the Church itself given the failure of the Declaration on Christian Education to set the 'agenda' for religious education. ${ }^{148}$ The challenge to teach the new theology was compounded by the increased role of lay teachers most of whom lacked the necessary formation to teach religion effectively. ${ }^{149}$ As a result, overall teachers did not focus on the teaching of theology but rather on the personal search for faith, which was considered as a process. For example, in the 1971 Report of the Christian Philosophy of Education Committee to the annual general meeting of the Ontario English Catholic Teachers" Association, a "living faith" was defined as "a continual conversion, a continual process" whose "laws of growth are based on the dynamics of human development," and not based "on objective evidence," but the "testimony and reliability of a Person - a faith, in short, that is personal." $" 150$

Another problem that led to confusion was the lack of a consistent approach to religious education, caused by the overall tendency towards decentralization and democratization of the existing authority structures. This tendency expressed itself in an increased emphasis on the important role of the local community. Rahner, for example, contended that the "most original religious and theological experience of the Church will take place...in the local community." 151 In his 1964 circular to the clergy and religious of his diocese, Bishop Carter also underlined the critical role of the local community when he stated that diocesan-wide institutions such as the Institutes for Adult Education could not "substitute for the work done at the local level," and later in 1970 he closed the Diocesan Office of Religious Education, arguing that "the only solution to the problem of religious education is on the local level i.e., the school board, the parish, the local school, etc." ${ }^{\prime 52}$ In emphasizing the local community, bishops were following the principle of subsidiarity, and were reluctant to interfere with either the schools or the boards responsible for the supervision of education. Moreover, with the decentralization of the Ministry of Education, these boards had considerably more responsibilities than before. Religious education was only one

\footnotetext{
${ }^{148}$ Despite this failure the Declaration was still often referenced in the diocese documents and used as a general guideline. This is not surprising given that it was the only Vatican II document on education and that it embodied the new style of discourse and the reflected the new orientation in religious education. For example, Diocese of London Synod reports, the Sub-Commission on Youth and Commission on Christian Education, refer to the Declaration several times. London Diocese Archives, DUA, Bishop E.G. Carter, Box 25, File 28 and G.E. Carter Religious Education, "Christian Education Report", B19.F13

${ }^{149}$ This was a major problem, beginning in the 1950s with the increased student enrolment and the declining number of religious available to teach religion, a dilemma that worsened with the religious crisis of the late 1960s. The bishops were well aware of lack of lay teachers' religious formation, highlighting in a 1961 report to the Ontario Ministry of Education that teacher colleges did not properly prepare Catholic teachers. Many of the colleges only offered one non-credited course in religious education. This problem persisted in the long sixties with Ontario teachers' colleges. It was only in the late 1970s that the colleges began to offer one credited course, an improvement yet even in 1961 the bishops contended that one course was not sufficient. This was not only a problem in Ontario. In this national report, Murchland noted that the "single greatest need... as reflected across the country is, of course, the need for teacher education." Murchland, Adolescent Catechesis, 37.

${ }^{150}$ Report of the Christian Philosophy of Education Committee, Archives of the Archdiocese of Toronto, EDS011.31.

${ }^{151}$ Karl Rahner, The Church After the Council (New York: Herder and Herder, 1966), 49.

152 Circular \# 10, 4. G.E. Carter Circulars 1923-1964 BS-F25 and 1970 letter to Mr. J. Havlik, Chair of the Essex County R.C. Separate School Board, Essex County B22-F2, 1. The perceived importance of the local community is also highlighted in a 1965 London Diocese memo to the principles providing a list of available textbooks, leaving it to the local school to select the appropriate ones: "If it does not seem suitable for your school (and not all texts will suit all school situations) experiment with another.” G.E. Carter Religious Education Fathers J.P. Finn/J.J.

O’Flaharty, 1960-1965, B19-F25.
} 
of their concerns. Furthermore, Catholic high schools at the senior level, grade 11-13, were private schools, which had little contact with each other even in the same board. Each school developed its own religious curriculum, choosing whatever resources they deemed worthwhile. ${ }^{153}$ Without a central authority providing some consistency, Catholic high schools acted in relative isolation, a difficult task given the cultural changes of the long sixties, particularly the religious crisis. ${ }^{154}$ Nor were these schools able to benefit from any guidance from the Vatican given both the importance attributed to the principle of subsidiarity and the overall weakness of the Declaration on Christian Education.

Evidence of confusion was thus widespread. For example, in a 1964 letter to Reverend G. Delcuve, Director of the International Centre for Religious Education in Belgium, the Superior General of the Basilian Fathers reported that one of the greatest problems in religious education was how to teach religion to high school students in the "proper way" and that "this area, as I'm sure you know, is one of great confusion and dissatisfaction for teachers themselves, and consequently for the students also." ${ }^{155}$ The Sisters of St. Joseph also experienced considerable confusion and trepidation, acknowledging in a 1969 report that "all educators must use the new approach," but that "more and more teachers, both religious and lay, were requesting release from religion teaching" for fear of "doing the Lord's work badly" and further alienating their students. ${ }^{156}$ For Bishop Carter the situation had become so serious that in 1968 he even considered a moratorium on "formal religion classes and above all in examinations in religion." 157 The very nature of religious education was called into question with many educators agreeing with Carter that religion should not be treated as an academic subject with the emphasis on teaching Church doctrine as it had been prior to Vatican II. With the focus now on the individual's inner transformation and personal development, how could religion be considered as an academic subject in which the students' performance was evaluated? How could a person's inner transformation be assessed? Members of the Sub-Commission on Youth for the London Diocese Synod were "convinced that what is needed is an approach to religion which will be more subjective and less impersonal. Obviously, religion cannot be imparted like an academic subject." $" 158$

\footnotetext{
${ }^{153}$ This was true even in schools belonging to the same religious order. For example, in 1962, the Basilian Fathers held the first meeting ever of their high school administrative officials with the purpose of establishing "better lines of communication between the six Basilian High Schools in Ontario." Archives of the Basilian Fathers, C3115.19. The same situation existed with the Sisters of St. Joseph, although efforts were made in the 1960s to have the schools co-operate with each other. However, such efforts do not seem to have been successful. In a 1981 Project Report, "St. Joseph's High Schools - Organizing for the Future" it was reported that "all Catholic High Schools appear to be run quite autonomously from one another", referring to the 33 high schools in the Archdiocese of Toronto, which included five Catholic school boards. Sisters of St. Joseph Archives, 200, 4-6, Box 4.

${ }^{154}$ Many of the documents attest to the challenging cultural changes. References to a "crisis of faith" were common. Murchland noted such a crisis in his report, listing the crisis of faith as one of many. Others included were the crises of values, of civilization, and of authority and leadership. Murchland, Adolescent Catechesis, 37.

${ }^{155}$ Archives of the Basilian Fathers, C. 3115.36. The Basilians had a long history in secondary education. In the 1960 s, they had six high schools in Ontario. C. 3115.23.

156 "Catholic Secondary Education", 4. Sister of St. Joseph Archives, 200 2-11, Box 5.

${ }^{157}$ Letter to Reverend James Grannan, London Diocese Archives, B19 F26. Later in a 1976 key note address, "Catholic Education in Context" delivered at the Annual Conference of the Federation of Catholic Education Associations of Ontario, Carter commented that even though Vatican II did not "intend to confuse the basic teachings of the Church", the "confusion arose afterwards. What happened was, and is, a real crisis of faith." The Spotlight: News \& Views on Catholic Education. Archives of Toronto Archdiocese, ED5008.15b.

${ }^{158}$ Sub-Commission Report on Youth, 4. London Diocese Archives, DUA, Bishop E.G. Carter, Box 25, File 28.
} 
Many Catholic educators were therefore struggling to define Catholic education, leading to serious questions of identity. The London Diocese convened an Inquiry Commission in 1975 to examine the Catholicity of Brennan High School after a series of complaints from the parent community. The Commission agreed with the parents, and issued several recommendations to improve the Catholicity of the school, including that the Chapel be given a more eminent position in the school and that the school regulations concerning behaviour adhere to Catholic principles. ${ }^{159}$ In a 1970 letter to his religious superior, a Basilian Father, Chair of the Catholic High Schools Principals' group, expressed concern for the "soul" of Catholic education, commenting that "we might be at the Rubicon right now" and need to think seriously about the Catholic nature of the schools "before we cross." ${ }^{160}$ Murchland's national report also highlighted this confusion over the nature of religious education: during the long sixties: "We have lost to some extent our vital core, our sense of purpose... We've become unglued, unraveled and disoriented. We are searching again for the renewed force and dynamism of our faith. It does not make it any easier in that this search must be carried out in the context of pluralism, relativity, disbelief, and secularism."161

Conclusion

The long sixties witnessed a fundamental shift in secondary religious education from the pre-Vatican II period, characterized by a Magisterium mandated strict Neo-Thomism and by traditional teacher-led pedagogy, to the post Vatican II period, which featured a more subjective approach with the individual students as the center of the learning process. Teaching methods also changed as students discussed issues and determined their own meaning. Their inner transformation and personal development were paramount.

This fundamental shift was caused by many factors, including the collapse of Catholic classicism as North American Catholics assimilated into the empiricist, secular culture in which they lived. Catholics experienced the cultural changes that resulted in a child-centred society which greatly valued individual and democratic rights; a society that also experienced a 'crisis of authority' with the youth challenging many of the traditional values. The impact of Vatican II was also significant as the Church accepted the subjectivity and pluralism of the new theology, and adopted the principle of subsidiarity. A new style of discourse was adopted, reflecting the new vision of the Church as the 'people of God.' The combined effect of the new secular, cultural values and those of Vatican II led to a much-needed reform of religious secondary education, especially with the new focus on the inner transformation and the lived experience of the individual.

The fundamental shift, however, was somewhat extreme, giving rise to considerable confusion about the nature of secondary religious education. Strict Neo-Thomism was abandoned, but not replaced by a coherent body of Church teachings that could be taught. Even the major Vatican II document on education, the Declaration, was the product of this confusion and failed to provide the much-needed direction for Catholic education. There was no consistent approach to education because of the combined effect of the principle of subsidiarity and the devolution of power from the Ministry of Education to the school boards. Most high schools were responsible for developing their own religion curriculum, although they did adopt the same student-centered, subjective approach, and did not consider religion as an academic subject.

\footnotetext{
159 "Report of the Special Commission of Inquiry in Regard to Brennan High School, Windsor, Ontario", 4-5. G.E. Carter High Schools Brennan Inquiry Commission, 1975. B11-F17.

${ }^{160}$ Letter to Reverend J.C. Wey, Superior-General, 2. Basilian Fathers Archives, C. 3115.24.

${ }^{161}$ Murchland, Adolescent Catechesis, 42.
} 
By the mid 1970s, a counter-shift began as many Catholics began to question the wisdom of not teaching Church doctrine. In both the Archdiocese of Toronto and the London Diocese there was a movement towards teaching more Church doctrine. One of the major recommendations of the Brennan High School Inquiry Commission was to improve the religion courses, which "appear to be more a sociology of religion than a course in Theology," by modifying them to "give greater emphasis to basic truths regarding God, the Church, the Sacraments, and the Liturgy."162 The school boards and the bishops also began to develop religion curriculum, providing the necessary leadership that was lacking during the long sixties. Catholic leadership also recognized that religion should be considered as an academic subject in order to emphasize the importance of Church teachings. ${ }^{163}$ In other words, Catholic educators were attempting to achieve a balance in religious secondary education with the focus on the individual's inner transformation and personal development as well as on the transmission of important Church teachings. It is a balance that Catholic educators have continued to attempt to maintain ever since the long sixties.

\footnotetext{
162 Report of the Special Commission, 5-6. G.E. Carter High Schools Brennan Inquiry Commission, 1975, B11-F17.

${ }^{163}$ Many educators realized that without the status of an 'academic subject' students tended not to take religion as seriously as their other courses. When the province of Ontario adopted the credit system in 1972 religion was not one of the accredited courses. It took seven years for Catholic educators to convince the government to change its mind. Even then, religion counted for only a half credit in grade 9 and grade 10 . At the senior level, still private and therefore not financially supported by the government, religion remained a non-credit course.
} 